\title{
FAKTOR RESISTENSI BURUH TERHADAP KEBIJAKAN SISTEM OUTSOURCING
}

\author{
Bayu Febrianto \\ banguyab08@gmail.com \\ Universitas Airlangga
}

\begin{abstract}
ABSTRAK
Resistensi sebagai respon negatif pekerja/ buruh saat dihadapkan pada perubahan kebijakan yang tidak sesuai. Tujuan dari penelitian ini adalah untuk mengungkap resistensi pekerja terhadap kebijakan sistem outsourcing dengan menggunakan pendekatan resistensi terhadap perubahan oleh Piderit. Penelitian ini menggunakan metode kualitatif dengan pendekatan fenomenologi. Penentuan subjek dilakukan dengan menggunakan snowball sampling. Subjek terdiri dari empat pekerja aktif di serikat pekerja dan perlawanan terhadap kebijakan sistem outsourcing. Teknik pengumpulan data menggunakan wawancara tidak terstruktur, observasi non partisipan, dan dokumentasi. Analisis data menggunakan reduksi data model interaktif, penyajian data, dan verifikasi kesimpulan oleh Miles dan Huberman. Hasil penelitian ini menunjukkan bahwa resistensi terhadap kebijakan sistem outsourcing dapat dilihat dari tiga hal yaitu afektif, kognitif, dan perilaku.

Kata Kunci: Tenaga Kerja, Resistensi, Afektif, Kognitif, Perilaku
\end{abstract}

\section{ABSTRACT}

Resistance as a negative response workers/labourers when faced with a change in a policy that does not fit. The purpose of this study is to reveal the workers' resistance to the policy outsourcing system by using the approach of resistance to change by Piderit. This study used qualitative methods with phenomenological approach. Determination of the subjects was done by using snowball sampling. The subjects consisted of four active workers in the trade unions and the resistance to the policy of outsourcing system. Data collection techniques using unstructured interviews, non-participant observation, and documentation. Data were analyzed using an interactive model of data reduction, the data display, and verification of conclusions by Miles and Huberman. The results of this study indicate that resistance to the policy of outsourcing system can be viewed from three things, namely affective, cognitive, and behavioral.

Keywords: Labour, Resistance, Affective, Cognitive, Behavioral

\section{PENDAHULUAN}

Salah satu peristiwa yang menonjol pada era pasca reformasi dalam dunia industri seperti perlawanan buruh, dan protes kepada pemilik perusahaan banyak bermunculan karena buruh merasa diperlakukan tidak layak. Pada umumnya perlawanan tersebut bertujuan untuk memperbaiki nasib, dan memenuhi kebutuhan hidupnya. Secara garis 
besar bentuk tuntutannya adalah kenaikan upah, dan perbaikan kondisi maupun fasilitas kerja. Tetapi adapun juga tuntutan buruh yang akhir-akhir ini menjadi isu nasional, salah satunya yaitu sistem outsourcing.

Terkait dengan sistem outsourcing, berdasarkan hukum ketenagakerjaan istilah outsourcing sebenarnya bersumber dari ketentuan yang terdapat dalam pasal 64 UndangUndang No. 13 Tahun 2003 tetang Ketenagakerjaan, yang menyatakan bahwa perusahaan dapat menyerahkan sebagian pelaksanaan pekerjaan kepada perusahaan lainnya dengan melalui perjanjian pemborongan pekerjaan atau yang biasa disebut penyediaan jasa pekerja yang dibuat secara tertulis. Menurut Latupono (2011), sistem kerja outsourcing diartikan sebagai pemindahan atau pendelegasian beberapa proses bisnis kepada suatu badan penyedia jasa, dimana badan penyedia jasa tersebut melakukan proses administrasi dan manajemen berdasarkan pada defenisi serta kriteria yang telah disepakati oleh para pihak.

Di dalam praktiknya, ketentuan tentang penyediaan jasa pekerja yang diatur dalam peraturan undang-undang tersebut pada akhirnya memunculkan istilah outsourcing. Sebagaimana yang dimaksud dalam hal ini perusahaan menggunakan sumberdaya manusia bukan dari dalam perusahaan, melainkan dari luar perusahaan. Menurut Damanik (2006), Pada praktik outsourcing, terdapat tiga pihak yang berhubungan dalam sistem tersebut, yaitu perusahaan pemberi kerja, perusahaan penerima kerja dan pekerja outsourcing itu sendiri.

Pemahaman terkait dengan sistem outsourcing mulai muncul sejak sistem outsourcing diatur dalam Undang-undang Nomor 13 Tahun 2003 tentang ketenagakerjaan, meskipun di dalam undang-undang tersebut tidak pernah disebutkan tentang istilah outsourcing, namun di dalam Undang-Undang Ketenagakerjaan No. 13 tahun 2003 Pasal 64 menyatakan bahwa perusahaan dapat menyerahkan sebagian pekerjaan kepada perusahaan lainnya melalui perjanjian pemborongan pekerjaan atau penyediaan jasa pekerja/ buruh yang dibuat secara tertulis. Ketentuan perusahaan menggunakan sistem outsourcing tersebut tidak diwajibkan, karena sebenarnya penggunaan pekerja outsourcing tergantung kepada perusahaan itu sendiri.

Dengan demikian terkait dengan penjelasan di atas, ketika perusahaan menyerahkan sebagian pekerjaan kepada perusahaan lain, dapat dilakukan dengan cara melalui perjanjian pemborongan pekerjaan yang telah dibuat secara tertulis. Akan tetapi 
dalam hal ini tidak semua pekerjaan dapat diserahkan untuk dikerjakan ke perusahan lain, melainkan harus memenuhi syarat-syarat dan ketentuan yang dilakukan secara terpisah dari kegiatan utama. Artinya ketentuan pekerjaan yang dapat diserahkan untuk dikerjakan ke perusahaan lain bersifat pekerjaan penunjang (non core bussiness).

Menurut Negara (2010), penggunaan outsourcing memiliki beberapa manfaat di dalamnya, hal ini merupakan salah satu pilihan yang strategis dalam mendukung proses bisnis di dalam perusahaan. Selain dalam rangka efisiensi, perusahaan pengguna dimanjakan dengan beberapa keuntungan atau manfaat dari kegiatan sistem tersebut. Satu yang terpenting diantaranya adalah perusahaan pengguna outsourcing dapat lebih fokus pada kegiatan inti core business, sehingga proses pencapaian tujuan perusahaan dapat lebih terkontrol, terukur dan akhirnya tercapai.

Menurut Yasar (Royen, 2009) manfaat outsourcing bagi masyarakat adalah untuk perluasan kesempatan kerja. Bagi pemerintah, pelaksanaan outsourcing memberikan manfaat untuk mengembangkan dan mendorong pertumbuhan ekonomi masyarakat dan pertumbuhan ekonomi nasional melalui pengembangan kegiatan usaha kecil menengah dan koperasi. Keberadaan perusahaan yang bergerak pada bidang outsourcing besar secara tidak langsung telah membantu pemerintah dalam mengatasi pengangguran (menyerap tenaga kerja) dengan menciptakan lapangan pekerjaan baik bagi diri mereka sendiri maupun orang lain, sehingga dapat mendorong kegiatan ekonomi dan meningkatkan daya beli masyarakat.

Terlepas dari penjelasan adanya beberapa manfaat outsourcing di atas, akan tetapi pada pelaksanaannya bahwa adanya kekurangan dalam pengawasan atas pemenuhan syarat-syarat outsourcing yang sulit dilakukan, sehingga penerapan sistem outsourcing di perusahaan juga banyak yang menyimpang. Terkait dengan penyimpangan penggunaan outsourcing, dapat di jelaskan oleh Latupono (2011), ketika suatu perusahaan menggunakan sistem outsourcing, maka akan menyebabkan perbedaan kedudukan dalam hubungan kerja antara pekerja dan pengusaha menjadi tidak seimbang. Dengan demikian, apabila tidak seimbang dapat berdampak pada posisi tawar pekerja menjadi semakin lemah, karena tidak ada kepastian kerja, kepastian upah, jaminan sosial, jaminan kesehatan, pesangon jika di PHK, tunjangan-tunjangan dan kepastian lain. Hal ini sangat kontradiktif dengan apa yang dibutuhkan dan apa yang diharapkan oleh buruh outsourcing untuk memenuhi kebutuhan hidupnya. 
Sama halnya dengan pernyataan Sutedi (2011) yang menyatakan bahwa, praktik sehari-hari dalam outsourcing selama ini diakui lebih banyak merugikan pekerja/ buruh, karena di dalam hubungan kerja tidak tetap atau kontrak (Perjanjian Kerja Waktu Tertentu), upah lebih rendah, jaminan sosial kalaupun ada hanya sebatas minimal, tidak adanya job security serta tidak adanya jaminan pengembangan karier, dan lain-lain. Dengan demikan memang benar bahwa di dalam keadaan seperti itu dapat dikatakan praktik outsourcing ini akan menyengsarakan pekerja/ buruh dan membuat redupnya hubungan industrial. Hal tersebut dapat terjadi karena sebelum adanya Undang-Undang No 13 tahun 2003 tentang Ketenagakerjaan, tidak ada satu pun peraturan perundangundangan di bidang ketenagakerjaan yang mengatur perlindungan terhadap pekerja/ buruh dalam melaksanakan outsourcing. Kalaupun memang ada, barangkali dengan adanya peraturan Menteri Tenaga Kerja No. KEP-100/MEN/VI/2004 tentang ketentuan pelaksanan Perjanjian Kerja Waktu Tertentu (PKWT), yang hanya merupakan salah satu aspek dari sistem outsourcing.

Adanya indikasi lemahnya perlindungan bagi pekerja/ buruh dapat terlihat pada permasalahan outsourcing yang akhir-akhir ini menjadi isu nasional yang aktual dan banyak menuai kontroversi, sehingga muncul pro dan kontra dari kaca mata publik terhadap sistem tersebut. Dalam beberapa tahun terakhir ini pelaksanaan sistem outsourcing dikaitkan dengan hubungan kerja, sangat banyak dibicarakan oleh pelaku proses produksi barang maupun jasa dan oleh pemerhati. Persoalan mengenai outsourcing memang cukup bervariasi seiring dengan penggunaannya yang semakin banyak digunakan dalam dunia usaha, oleh karenanya sistem outsourcing menjadi pilihan utama untuk kepentingan usaha. Akan tetapi pada pelaksanaannya, sistem outsourcing merugikan para pekerja/ buruh, sehingga dapat menimbulkan keresahan pekerja/ buruh dan tidak jarang diikuti dengan tindakan resistensi.

Resistensi ini merupakan suatu perlawanan ataupun penolakan kepada perubahanperubahan yang terjadi dan yang tidak sesuai. Menurut Barnard dan Jonathan (Suriadi, 2008), resistensi ini sebenarnya merupakan tindakan yang dilakukan oleh masyarakat lemah, seperti buruh yang berada pada struktur bawah terhadap pihak kuat yang berada pada struktur atas seperti penguasa maupun pengusaha. Dalam hal ini hubungan di antara satu pihak yang lemah dan pihak lain yang kuat bahwa sesungguhnya berada pada suatu hubungan kekuasaan yang tidak seimbang. Oleh karena itu, dengan adanya hubungan 
kekuasaan yang tidak seimbang, maka pihak lemah yang berada pada struktur bawah berusaha menyeimbangkan hubungan mereka melalui resistensi agar tidak terlalu tertekan ataupun tertindas.

Menurut Purwanto (Erman dan Saptari, 2013) menyatakan bahwa di awal tahun 2012, ruang media massa Indonesia dihiasi oleh berbagai berita tentang aksi besarbesaran para buruh di dalam negeri, mulai dari pemogokan konvensional sampai tindakan para buruh menutup jalan masuk ke lokasi pusat produksi dan menduduki ruang publik seperti jalan tol. Padahal sebelum aksi buruh yang berskala besar seperti itu biasanya hanya marak dilakukan pada waktu-waktu tertentu, terutama menjelang perayaan hari buruh sedunia atau (May Day). Aksi-aksi tersebut tidak hanya terjadi di pusat-pusat industri di Jawa, namum berlangsung secara merata di pulau-pulau lainnya termasuk Papua.

Menurut Muftakhir (2012) sebagai gambaran, pada tahun 2006 sampai 2007 berbagai serikat buruh serentak melakukan perlawanannya di berbagai kota berhasil menentang rencana pemerintah untuk merevisi UU No.13/ 2003 tersebut. Kemudian hingga tanggal 3 Oktober 2012, merupakan tanggal yang monumental dalam sejarah gerakan buruh Indonesia pasca kediktatoran rezim orde baru, karena pada saat itu beberapa serikat buruh turun ke jalan untuk menuntut penghapusan sistem kerja outsourcing, penolakan upah murah dan pelaksanaan jaminan sosial. Aksi protes dan perlawanan buruh pun masih mempersoalkan hal serupa, seolah kurang lengkap jika sebuah gerakan, menanggalkan isu tersebut, yaitu sistem outsourcing. Mengenai hal ini dalam setiap momentum gerakan buruh, isu outsourcing seolah selalu menjadi yang pertama dan utama dalam setiap aksi buruh.

Signifikansi dari peristiwa-peristiwa seperti di atas memperlihatkan adanya peningkatan resistensi dan militansi buruh yang selama ini mengalami berbagai kerugian baik secara ekonomi maupun sosial. Membicarakan gerakan buruh dan berbagai resistensinya sangat menarik, karena hal itu menyangkut dengan sebuah upaya peningkatan kesejahteraan dan pemenuhan kebutuhan hidupnya. Dengan demikian terjadinya resistensi menurut Suriadi (2008), dapat disebabkan oleh tiga faktor, yaitu: Pertama, faktor sosio-psikologis, Kedua, faktor sistem budaya yang sudah tidak sesuai lagi tatanan nilai dan norma yang telah terinternalisasi dalam tatanan kehidupan para buruh. Ketiga, faktor struktural yakni adanya kondisi struktural (sosial politik) yang 
memungkinkan buruh mempunyai ruang gerak untuk memanifestasikan dalam berbagai aspirasinya.

Resistensi buruh pun kerap kali muncul terhadap perubahan kebijakan, karena banyak permasalahan yang akan timbul pada saat perubahan akan dilakukan. Menurut Piderit (2000), menjelaskan bahwa resistensi merupakan sebagai respon negatif pekerja ketika menghadapi perubahan yang berasal dari tiga dimensi, yaitu komponen afektif, komponen kognitif dan komponen perilaku. Komponen afektif melihat bagaimana perasaan ketika terjadi perubahan, kemudian komponen kognitif mengarah pada pikiran ketika terjadi perubahan, dan komponen perilaku yang mencakup tindakan yang memberi respon pada perubahan.

Kemudian bentuk dari resistensi sendiri menurut Aminah (Arifin dkk, 2012), secara umum bentuk-bentuk resistensi terdiri dari dua jenis, yaitu: resistensi aktif dan resistensi pasif. Sedangkan bentuk tipikal resistensi yang sering dilakukan oleh buruh menurut Scott dan James (Suriadi, 2008) dapat dibagi menjadi tiga bentuk, yaitu: resistensi tertutup, resistensi semi terbuka, dan resistensi terbuka. Dengan demikian apapun bentuk dan beragamnya tuntutan para buruh, unjuk rasa diyakini oleh para buruh sebagai pilihan strategis yang bersifat kolektif dan efektif sebagai sarana untuk memperkuat posisi tawarmenawar (bargain position) buruh terhadap perusahaan dan pemerintah. Meski berhenti bekerja dan berunjuk rasa (strike) bukan satu-satunya sarana, akan tetapi hal tersebut merupakan senjata yang ampuh bagi para buruh, dan ditakuti jika bersifat massal, kolektif dan terorganisasi (Virianita, dkk, 2003).

Sebenarnya mengenai sistem outsourcing di Indonesia ini, apabila di lihat dari sisi regulasi dan penerapannya selalu menjadi fenomena yang menarik untuk dikaji. Isu outsourcing selalu hangat, karena terkait dengan dampak kehidupan ketenagakerjaan yang sangat dinamis. Di satu sisi, perusahaan ingin memberdayakan sumber daya dari luar (outsourcing) untuk fokus pada pekerjaan inti dan mengembangkan usaha bisnisnya, di sisi lain pekerja/ buruh keberatan dan menolak. Hal ini dikarenakan adanya praktik outsourcing diduga merugikan pihak tertentu yaitu, buruh.

Dari beberapa penjelasan sebelum-sebelumnya di atas, persoalan reaksi buruh beserta resistensi lainnya saat ini merupakan persoalan yang serius dan memerlukan refleksi secara mendalam oleh semua pihak. Kenyataan tersebut secara langsung menimbulkan berbagai pemikiran yang berhubungan dengan adanya keadaan yang dapat 
dikategorikan sebagai sesuatu yang luar biasa sedang terjadi di dalam diri para buruh yang tidak lagi mampu dimediasi dengan cara yang selama ini dilakukan. Hal ini sekaligus menunjukkan bahwa masalah yang ada di sekitar buruh tidak serta-merta dapat dipahami sekedar sebagai kenyataan sosial semata, melainkan juga persoalan psikologis yang berhubungan dengan pikiran, reaksi emosional dan tingkah laku mereka. Oleh karena itu berdasarkan uraian di atas, peneliti tertarik untuk menganalisis secara fenomenologi, yang nantinya dituangkan dalam bentuk penelitian dengan judul "Resistensi Buruh Terhadap Kebijakan Sistem Outsourcing.

\section{LANDASAN TEORI}

\section{A. Sistem Outsourcing (Alih Daya)}

1. Definisi Outsourcing

Menurut Latupono (2011), sistem kerja outsourcing diartikan sebagai pemindahan atau pendelegasian beberapa proses bisnis kepada suatu badan penyedia jasa, dimana badan penyedia jasa tersebut melakukan proses administrasi dan manajemen berdasarkan pada defenisi serta kriteria yang telah disepakati oleh para pihak. Sedangkan menurut Widjaja (Royen, 2009) mengatakan outsourcing adalah suatu proses dimana sumber-sumber daya dibeli dari orang lain melalui kontrak jangka panjang sebagai ganti yang dulunya dibuat sendiri oleh perusahaan. Pengertian tersebut lebih menekan pada istilah yang berkaitan dengan proses "alih daya" dari suatu proses bisnis melalui sebuah perjanjian/ kontrak.

Secara khusus Undang-Undang No. 13 Tahun 2003 membagi bentuk sistem hubungan kerja antara buruh dan majikan, yaitu: PKWT (Perjanjian Kerja Waktu tertentu), PKWTT (Perjanjian Kerja Waktu Tak Tertentu), dan Borongan Pekerjaan. Di dalam Undang-Undang Ketenagakerjaan tidak menyebutkan secara tegas mengenai istilah outsourcing, tetapi pengertian outsourcing dapat dilihat dalam ketentuan Pasal 64 Undang-Undang Ketenagakerjaan No. 13 Tahun 2003. Berdasarkan hukum ketenagakerjaan, menurut Sutedi (2011), istilah outsourcing sebenarnya bersumber dari ketentuan yang terdapat dalam pasal 64 Undang-Undang No. 13 Tahun 2003 tentang Ketenagakerjaan, yang menyatakan bahwa perusahaan dapat menyerahkan sebagian pelaksanaan pekerjaan kepada perusahaan lainnya melalui perjanjian pemborongan pekerjaan atau penyediaan jasa pekerja yang dibuat secara tertulis. 


\section{Konsep Outsourcing}

Menurut Royen (2009), konsep outsourcing merupakan pendelegasian operasi dan manajemen harian dari suatu proses bisnis kepada pihak luar (perusahaan penyedia jasa outsourcing). Melalui pendelegasian, maka pengelolaan tak lagi dilakukan oleh perusahaan, melainkan dilimpahkan kepada perusahaan jasa outsourcing. Pada praktik outsourcing, terdapat tiga pihak yang berhubungan dalam sistem tersebut, yaitu perusahaan pemberi pekerjaan, perusahaan penerima pekerjaan dan pekerja outsourcing itu sendiri.

3. Pengguna Outsourcing di Perusahaan

Survei dilakukan oleh Divisi Riset PPM Manajeman pada tahun 2008, yang menggunakan kuesioner dengan convinience sampling kepada 44 perusahaan dari berbagai industri di Indonesia. Berdasarkan hasil survei diketahui bahwa terdapat $73 \%$ perusahaan menggunakan tenaga outsource dalam kegiatan operasionalnya, sedangkan sisanya yaitu $27 \%$ tidak menggunakan tenaga outsource. Dari $73 \%$ perusahaan yang sepenuhnya menggunakan tenaga outsource merupakan jenis industri perbankan, kertas, jasa pendidikan, pengolahan karet dan plastik, serta industri makanan dan minuman. Sedangkan industri alat berat, mesin dan sarana transportasi, seperti otomotif dan suku cadang menggunakan tenaga outsource sebanyak 57.14\%. Untuk industri farmasi dan kimia dasar sebanyak $80 \%$, kemudian industri telekomunikasi dan informasi teknologi sebanyak $60 \%$, dan industri lainnya sebanyak 50\% terdiri dari industri jasa pemeliharaan pembangkit listrik, konsultan, EPC (enginering procurement, construction), pengolahan kayu, kesehatan, percetakan dan penerbitan, dan elektronik. Jika dilihat dari status kepemilikan, diketahui bahwa BUMN, Joint Venture dan Nirlaba menggunakan 100\% tenaga outsource dalam kegiatan operasionalnya. Sedangkan untuk swasta nasional menggunakan tenaga outsource sebanyak 57.69\% dan swasta asing menggunakan sebanyak $85.71 \%$. Dari $73 \%$ perusahaan itu pun yang menggunakan tenaga outsource diketahui 5 alasan menggunakan outsourcing, yaitu agar perusahaan dapat fokus terhadap core business sebanyak 33,75\%, untuk menghemat biaya operasional sebanyak $28,75 \%$, turn over karyawan menjadi rendah sebanyak 15\%, dan modernisasi dunia usaha dan lainnya, masing-masing sebesar 11,25\%. Adapun yang menjadi alasan lain, seperti: efektifitas manpower dan lain-lain. 


\section{Manfaat Outsourcing}

Kecenderungan beberapa perusahaan untuk mempekerjakan pekerjanya dengan sistem outsourcing menurut (Sutedi, 2011), umumnya dilatarbelakangi oleh strategi perusahaan untuk melakukan efisiensi biaya produksi (cost of production). Dengan menggunakan sistem outsourcing pihak perusahaan berusaha untuk menghemat pengeluaran dalam membiayai sumber daya manusia (SDM) yang bekerja di perusahaan yang bersangkutan.

Penggunaan outsourcing (alih daya) merupakan salah satu pilihan strategis dalam mendukung proses bisnis di perusahaan. Selain dalam rangka efisiensi, perusahaan pengguna dimanjakan dengan beberapa keuntungan atau manfaat dari kegiatan sistem outsourcing tersebut. Satu yang terpenting diantaranya adalah perusahaan pengguna outsourcing dapat lebih fokus pada kegiatan inti core business, sehingga proses pencapaian tujuan perusahaan dapat lebih terkontrol, terukur dan akhirnya tercapai (Negara, 2010).

Menurut Pearce dan Robinson (Royen, 2009), Bagi perusahaan-perusahaan besar outsourcing sangat bermanfaat untuk meningkatkan keluwesan dan kreativitas usahanya dalam rangka meningkatkan fokus bisnis, menekan biaya produksi, menciptakan produk unggul yang berkualitas, mempercepat pelayanan dalam berbagai masalah termasuk ketenagakerjaan. Dengan adanya outsourcing, memberi peluang kepada pegusaha untuk melakukan efisiensi dan meghindari risiko/ ekonomis beban yang berkaitan dengan masalah ketenagakerjaan.

Adapun juga manfaat outsourcing bagi masyarakat menurut Yasar (Royen, 2009), adalah untuk perluasan kesempatan kerja. bagi pemerintah, pelaksanaan outsourcing memberikan manfaat untuk mengembangkan dan mendorong pertumbuhan ekonomi masyarakat dan pertumbuhan ekonomi nasional melalui pengembangan kegiatan usaha kecil menengah dan koperasi. Keberadaan perusahaan yang bergerak pada bidang outsourcing besar secara tidak langsung telah membantu pemerintah dalam mengatasi pengangguran (menyerap tenaga kerja) dengan menciptakan lapangan pekerjaan baik bagi diri mereka sendiri maupun orang lain, mendorong kegiatan ekonomi dan meningkatkan daya beli masyarakat.

\section{Kontra Terhadap Sistem Outsourcing}

Terlepas dari itu semua, dalam pelaksanaannya bahwa adanya kekurangan dalam 
pengawasan atas pemenuhan syarat-syarat outsourcing yang sangat sulit dilakukan. Oleh karena itu penerapan sistem outsourcing di dalam perusahaan juga banyak yang menyimpang. Terkait dengan hal ini menurut Latupono (2011), ketika perusahaan menggunakan sistem outsourcing, maka akan menyebabkan perbedaan kedudukan dalam hubungan kerja antara pekerja dan pengusaha menjadi tidak seimbang. Apabila tidak seimbang, dapat berdampak pada posisi tawar pekerja menjadi semakin lemah, karena tidak ada kepastian kerja, kepastian upah, jaminan sosial, jaminan kesehatan, pesangon jika di PHK, tunjangan-tunjangan dan kepastian lain. Dengan demikian, hal ini sangat kontradiktif dengan apa yang dibutuhkan dan apa yang diharapkan oleh pekerja/ buruh outsourcing untuk memenuhi kebutuhan hidupnya.

Sama halnya dengan pernyataan Sutedi (2011) yang menyatakan bahwa, praktik sehari-hari dalam outsourcing selama ini diakui lebih banyak merugikan pekerja/ buruh, karena hubungan kerja tidak tetap/ kontrak (Perjanjian Kerja Waktu Tertentu), upah lebih rendah, jaminan sosial kalaupun ada hanya sebatas minimal, tidak adanya job security serta tidak adanya jaminan pengembangan karier, dan lain-lain. Dengan demikian memang benar bahwa dalam keadaan yang seperti itu dapat dikatakan bahwa praktik kerja di dalam sistem outsourcing ini dapat menyengsarakan pekerja/ buruh dan membuat redupnya hubungan industrial yang harmonis.

\section{B. Resistensi}

\section{Definisi Resistensi}

Menurut Chaplin, (2009) dalam kamus lengkap psikologi, telah ditentukan beberapa batasan pengertian terkait dengan resistance (resistensi) sebagai berikut: Aksi suatu tubuh menentang suatu kekuatan; Perlawanan satu sirkuit atau perjalanan keliling sepanjang perjalanan suatu arus listrik; (Psikoanalisis) upaya pasien untuk menghindari kemunculan material yang tidak disadari menuju kearah kesadaran; Oposisi sosial atau negativisme dalam mereaksi terhadap perintah, peraturan, kebijakan politik, dan seterusnya; Tahap pertama dari sindrom adaptasi, hingga tubuh dapat memobilisasikan sumber-sumbernya guna mengatasi ketegangan atau tekanan.

Adapun juga resistensi menurut Barnard dan Jonathan (Suriadi, 2008), resistensi merupakan suatu perlawanan ataupun penolakan untuk memprotes perubahan-perubahan yang terjadi dan yang tidak sesuai. Resistensi ini sebenarnya merupakan tindakan dilakukan oleh masyarakat lemah seperti buruh yang berada pada struktur bawah terhadap 
pihak kuat yang berada pada struktur atas atau penguasa dan pengusaha. Hubungan di antara satu pihak yang lemah (buruh) dan pihak lain yang kuat (pengusaha) sesungguhnya berada pada suatu hubungan kekuasaan yang tidak seimbang. Karena hubungan kekuasaan yang tidak seimbang, maka pihak lemah yang berada pada struktur bawah berusaha menyeimbangkan hubungan mereka melalui resistensi agar tidak terlalu tertekan ataupun tertindas.

2. Faktor-Faktor Terjadinya Resistensi

Terjadinya resistensi menurut Suriadi (2008), dapat diakibatkan oleh tiga faktor. Pertama, faktor sosio-psikologis yakni keadaan sosial yang mempengaruhi psikologis. Seperti halnya buruh melakukan protes yang terjadi karena adanya kesenjangan antara harapan dan kenyataan yang dialami oleh buruh. Dalam hal ini buruh melakukan protes ataupun aksi, dengan tujuan harapannya akan sesuai dengan kenyataan-kenyataan yang telah terjadi. Kedua, faktor sistem budaya yang sudah tidak sesuai lagi tatanan nilai dan norma yang telah terinternalisasi dalam tatanan kehidupan para buruh. Ketiga, faktor struktural yakni adanya kondisi struktural (sosial politik) yang memungkinkan buruh mempunyai ruang gerak dalam memanifestasikan aspirasinya.

Kemudian menurut J. Smelser (Sihbudi dan Nurhasim, 2001) menyatakan bahwa gerakan sosial seperti perlawanan ataupun resistensi ditentukan oleh lima faktor. Pertama, daya dukung (structural condusiveness) dimana suatu perlawanan akan mudah terjadi dalam suatu lingkungan atau masyarakat tertentu yang berpotensi untuk melakukan suatu gerakan massa secara spontan dan berkesinambungan (seperti lingkungan kampus, buruh, petani, dan sebagainya). Kedua, adanya tekanan-tekanan struktural (struktural strain) akan mempercepat orang untuk melakukan gerakan massa secara spontan karena keinginan mereka untuk melepaskan diri dari situasi yang menyengsarakan. Ketiga, menyebarkan informasi yang dipercayai oleh masyarakat luas untuk membangun perasaan kebersamaan dan juga dapat menimbulkan kegelisahan kolektif akan situasi yang dapat menguntungkan tersebut. keempat, faktor yang dapat memancing tindakan massa karena emosi yang tidak terkendali (triggering incidence), seperti adanya rumor atau isu-isu yang bisa membankitkan kesadaran kolektif untuk melakukan perlawanan. Kelima, upaya mobilisasi orang-orang untuk melakukan tindakan yang telah direncanakan (Mobilization for actions).

Menurut Piderit (2000), menjelaskan bahwa resistensi merupakan sebagai respon 
negatif pekerja ketika menghadapi perubahan yang berasal dari tiga dimensi, yaitu komponen afektif, komponen kognitif dan komponen perilaku. Komponen afektif melihat bagaimana perasaan ketika terjadi perubahan, kemudian komponen kognitif mengarah pada pikiran ketika terjadi perubahan, dan komponen perilaku yang mencakup tindakan yang memberi respon pada perubahan. Mengenai hal ini dapat disimpulkan bahwa resistensi sebagai kecenderungan individu untuk menghindari atau menolak perubahan yang terdiri dari beberapa komponen, yaitu: komponen kognitif, afektif, dan perilaku yang direpresentasikan melalui serangkaian respon negatif terhadap perubahan.

\section{Bentuk-bentuk Resistensi}

Bentuk tipikal resistensi yang sering dilakukan oleh buruh menurut Scott dan James (Suriadi, 2008) dapat dibagi menjadi tiga bentuk. Bentuk-bentuk tipikal resistensi tersebut dapat dilihat sebagai berikut; Pertama, resistensi tertutup (simbolis/ideologi) seperti gosip, fitnah, penolakan terhadap kategori-kategori yang dipaksakan kepada masyarakat/ buruh, serta penarikan kembali rasa hormat kepada pihak penguasa. Bentuk resistensi ini muncul karena tidak berpretensi mengubah sistem dominasi, tetapi hanya untuk menolak sistem yang berlaku, yang bersifat eksploitatif dan tidak adil. Kedua, resistensi semi terbuka seperti protes sosial dan demonstrasi mengajukan klaim kepada pihak yang berwenang. Bentuk resistensi ini diwujudkan untuk menghindari kerugian yang lebih besar yang dapat menimpa dirinya. Ketiga, resistensi terbuka merupakan bentuk resistensi yang terorganisir, sistematis, dan berprinsip. Resistensi terbuka ini mempunyai dampak-dampak yang revolusioner (yang mendukung perubahan mendadak, cepat, dan drastis). Tujuannya adalah berusaha meniadakan dasar dari dominasi itu sendiri. Manifestasi (wujud) dari bentuk resistensi ini adalah digunakannya cara-cara kekerasan (violent) seperti pemberontakan.

\section{METODE PENELITIAN}

\section{Partisipan dan Desain Penelitian}

Peneltian ini menggunakan metode penelitian kualitatif dengan pendekatan fenomenologi. Metode penelitian kualitatif dengan pendekatan fenomenologi merupakan penelitian yang bermaksud untuk memahami fenomena tentang apa yang dialami oleh subjek penelitian dan berusaha memahami arti peristiwa dan kaitan-kaitannya terhadap subjek yang berada dalam situasi-situasi tertentu (Iskandar, 2009). Dalam proses penentuan subjek dalam penelitian ini menggunakan pendekatan purposive sampling 
yaitu pengambilan sampel dengan pertimbangan tertentu menggunakan teknik snowball sampling yang merupakan teknik pengambilan sampel sebagai sumber data, yang pada awalnya jumlahnya sedikit, lama-lama menjadi besar. Dalam penelitian ini terdapat 4 subyek yang kriterianya adalah buruh yang aktif di dalam organisasi serikat buruh dan ikut serta dalam melakukan resistensi terhadap kebijakan sistem outsourcing. Teknik analisis data dalam penelitian ini menggunakan model interaktif Miles dan Huberman, dimana pada teknik ini terdapat tiga macam tahapan dalam analisis, yaitu reduksi data, data display, dan verifikasi kesimpulan.

\section{Teknik Pengumpulan Data dan Prosedur Penelitian}

Adapun juga teknik pengumpulan data yang dilakukan oleh peneliti dengan cara observasi non-partisipan, wawancara semi terstruktur, dan dokumentasi. Dengan demikian dalam penelitian ini menggunakan dua jenis data yaitu data primer dan data sekunder. Data primer pada penelitian ini yaitu buruh yang aktif di dalam organisasi serikat buruh dan ikut serta dalam melakukan resistensi terhadap kebijakan sistem outsourcing. Sedangkan data sekunder pada penelitian ini yaitu teman terdekat subjek atau teman satu serikat dan lewat pendokumentasian aktivitas subjek berupa foto.

Pada penelitian ini prosedur penelitian bermula dari penyusunan guide line interview yang kemudian guide line tersebut menjadi acuan untuk melakukan wawancara kepada subjek dengan menggunakan pendekatan purposive sampling, dan dengan pertimbangan tertentu menggunakan teknik snowball sampling. Adapun juga pengambilan data dengan menggunakan observasi non-partisipan dan menggunakan dokumentasi. Kemudian keseluruhan data yang telah didapat dari hasil wawancara di analisa menggunakan model interaktif Miles dan Huberman.

\section{HASIL}

\begin{tabular}{|c|c|c|c|c|c|}
\hline No & Identitas Subjek & Subjek 1 & Subjek 2 & Subjek 3 & Subjek 4 \\
\hline 1. & Nama Inisial & $\mathrm{BP}$ & AN & BM & ZL \\
\hline 2. & Usia & 42 tahun & 40 tahun & 42 tahun & 45 tahun \\
\hline 3. & Asal Kota & Gresik, Jawa Timur & Gresik, Jawa Timur & $\begin{array}{l}\text { Kendal, } \\
\text { Tengah }\end{array}$ & Gresik, Jawa Timur \\
\hline 4. & Jenis Kelamin & Laki-laki & Laki-laki & Laki-laki & Laki-laki \\
\hline 5. & Status Perkawinan & Menikah & Menikah & Menikah & Menikah \\
\hline 6. & $\begin{array}{l}\text { Pendidikan } \\
\text { Terakhir }\end{array}$ & S1 & $\mathrm{S} 1$ & S1 & S1 \\
\hline 7. & Satus Pekerjaan & $\begin{array}{l}\text { Tetap bagian } \\
\text { Smelter/ proses di } \\
\text { PT Smelting Gresik }\end{array}$ & $\begin{array}{l}\text { Tetap bagian } \\
\text { Smelter/ proses di } \\
\text { PT Smelting Gresik }\end{array}$ & $\begin{array}{l}\text { Tetap bagian } \\
\text { Smelter/ proses di } \\
\text { PT Smelting Gresik }\end{array}$ & $\begin{array}{l}\text { Tetap bagian } \\
\text { Smelter/ proses di } \\
\text { PT Smelting Gresik }\end{array}$ \\
\hline 8. & Lama & 15 tahun & 13 tahun & 15 tahun & 18 tahun \\
\hline 9. & Status Keserikatan & $\begin{array}{l}\text { Anggota Serikat } \\
\text { FSPMI PUK PT. } \\
\text { Smelting Gresik }\end{array}$ & $\begin{array}{l}\text { Anggota Serikat } \\
\text { FSPMI PUK PT. } \\
\text { Smelting Gresik }\end{array}$ & $\begin{array}{l}\text { Pengurus div. Garda } \\
\text { Metal FSPMI PUK } \\
\text { PT. Smelting Gresik }\end{array}$ & $\begin{array}{l}\text { Ketua Serikat } \\
\text { FSPMI PUK PT. } \\
\text { Smelting Gresik }\end{array}$ \\
\hline
\end{tabular}


Berdasarkan tabel di atas dapat diketahui bahwa:

1. $\mathrm{BP}$

Subjek BP yang saat ini berusia 42 tahun dan berjenis kelamin laki-laki serta berstatus menikah telah memiliki 2 orang putra. Subjek BP merupakan buruh PT. Smelting Gresik pada bagian Smelter atau bagian proses produksi dengan masa kerja selama 15 tahun. Selama masa kerja 15 tahun di PT. Smelting Gresik, subjek telah banyak mengalami suka maupun duka sebagai seorang buruh. Pada saat itu awal mula subjek pernah terlibat dalam aksi dan protes di tempatnya bekerja. Sejak saat itulah kemudian subjek bergabung dalam serikat, bahkan mengajak buruh-buruh yang lain untuk bergabung dengan serikat juga, dan memperjuangkan hak-hak buruh ketika terjadi pelanggaran seperti yang saat ini lagi ramai dibicarakan, yaitu mengenai sistem outsourcing. Alasan subjek bergabung di serikat FSPMI PUK PT. Smelting Gresik pada awalnya ia enggan untuk bergabung dengan serikat, namun karena dulunya subjek pernah mendapatkan bantuan saat mengalami sebuah kasus, maka subjek perlu membalas jasa tersebut dengan cara mengikuti serikat buruh dan membantu buruh-buruh yang lainnya.

2. $\mathrm{AN}$

Subjek AN yang saat ini berusia 42 tahun dan berjenis kelamin laki-laki serta berstatus menikah berdomisili Gresik. Subjek AN merupakan buruh PT. Smelting Gresik pada bagian Smelter atau bagian proses produksi dengan masa kerja cukup panjang. Subjek yang saat ini sebagai anggota serikat FSPMI PUK menuturkan bahwa beberapa tahun yang lalu di tempat subjek bekerja pernah terjadi konflik antara pihak perusahaan dengan pekerja. Perselisihan antara pihak manajemen dengan pihak pekerja disebabkan karena perusahaan di tempatnya bekerja pernah melakukan beberapa pelanggaran atau kecurangan yang merugikan subjek dan buruh-buruh yang lain. Kejadian tersebut pada akhirnya membuat subjek AN tertarik untuk bergabung di serikat saat mendapat ajakan oleh rekannya yaitu subjek BP sampai saat ini.

3. $\mathrm{BM}$

Subjek BM yang saat ini berusia 42 tahun dan berjenis kelamin laki-laki berasal dari Kendal, Jawa Tengah. Status subjek telah menikah dan saat ini memiliki 3 orang anak. Subjek BM telah bekerja selama 15 tahun di PT. Smelting Gresik pada bagian Smelter atau bagian proses poduksi. Dia pernah terlibat dalam aksi unjuk rasa di tempat ia bekerja, Dari kejadian ini subjek BM tertarik untuk bergabung dengan serikat, karena 
subjek memang peduli dengan buruh-buruh yang lain dan ingin membantu serta memperjuangkan hak-hak buruh yang lain. Sampai saat ini pun, dia tetap bergabung dalam serikat FSPMI sebagai divisi garda metal atau garda pengaman. Dari kejadian ini subjek BM tertarik untuk bergabung dengan serikat, karena subjek memang peduli dengan buruh-buruh yang lain dan ingin membantu buruh yang lain. Sampai saat ini pun, dia tetap bergabung dalam serikat FSPMI sebagai divisi garda metal atau garda pengaman.

4. ZL

Subjek ZL yang saat ini berusia 45 tahun dan berjenis kelamin laki-laki serta berstatus menikah telah memiliki 2 orang putra. Subjek ZL bekerja di PT. Smelting Gresik pada bagian Smelter atau bagian proses produksi. Dari awal bekerja, subjek telah mengikuti organisasi serikat buruh yang dulunya bernama SKS (Serikat Karyawan Smelting), dan bisa dibilang subjek adalah sebagai ketua di serikat FSPMI PUK PT. Smelting Gresik.

\section{DISKUSI}

Berdasarkan hasil penelitian, terjadinya resistensi terhadap kebijakan sistem outsourcing yang dilakukan oleh subjek BP, AN, BM, dan ZL dapat diketahui bahwa setiap subjek memilki pemikiran yang sama bahwa sistem outsourcing merupakan suatu sistem yang merugikan buruh, sehingga mereka melakukan resistensi untuk menuntut sistem tersebut agar dihapus. Semua pemahaman yang dijelaskan oleh subjek mengenai pelanggaran-pelanggaran yang terjadi di dalam praktek kerja sistem outsourcing, dapat dikatakan bahwa sistem tersebut sangat tidak sesuai dengan norma yang berlaku di dalam undang-undang ketenagakerjaan, sehingga tidak menutup kemungkinan banyak terjadinya resistensi di sektor industri dengan menuntut sistem tersebut agar dihapus.

Aksi tersebut merupakan tanggal yang monumental dalam sejarah gerakan buruh Indonesia pasca kediktatoran rezim orde baru. Pada saat itu beberapa serikat buruh melakukan resistensi berupa aksi demonstrasi dengan tuntutan HOSTUM (Hapus Outsourcing dan Tolak Upah Murah), yang dimana massa aksi menuntut penghapusan sistem kerja outsourcing, penolakan upah murah dan pelaksanaan jaminan sosial. Akan tetapi aksi tersebut mendapatkan hasil berupa tuntutan mengenai upah disetujui, sedangkan tuntutan mengenai hapus sistem outsourcing masih belum disetujui. Hal ini menyebabkan beberapa serikat buruh beserta massa aksinya melakukan aksi demonstrasi 
kembali pada bulan November, dan akhir dari aksi lanjutan tersebut mendapatkan hasil bahwa sistem outsourcing tidak dihapus, melainkan direvisi. Berdasarkan data yang diperoleh dari masing-masing subjek selama penelitian memang cukup beragam, akan tetapi resistensi yang di lakukan oleh masing-masing subjek saling melengkapi. Resistensi tersebut secara garis besar berasal dari kognitif, afektif dan perilaku yang kemungkinan sebagai respon subjek dalam melakukan resistensinya.

Terkait dengan hal ini dapat di lihat bahwa ketika sistem outsourcing direvisi, membuat keempat subjek tersebut muncul beberapa reaksi dalam ranah kognitifnya. Berdasarkan percakapan antara peneliti dengan subjek BP yang mengatakan bahwa dia heran dengan hasil yang telah ditetapkan, karena sistem outsourcing sudah dituntut berkali-kali agar dihapus, tetapi akhirnya sistem tersebut direvisi. Kemudian subjek AN yang muncul kejanggalan setelah mengetahui bahwa hasil akhir yang telah ditetapkan adalah sistem outsourcing direvisi. Subjek BM pun masih menentang sistem outsourcing walaupun sistem tersebut telah direvisi, sedangkan subjek ZL muncul kecurigaan terhadap hasil yang telah ditetapkan. Dengan demikian, adanya kesamaan pada setiap subjek ketika terjadi perubahan di dalam sistem outsourcing, yaitu masih belum bisa menerima atau dapat dikatakan bahwa setiap subjek masih belum puas dengan hasil yang telah diperoleh, sehingga membuat subjek meninjau ulang sistem tersebut.

Meskipun sistem outsourcing telah direvisi, akan tetapi setiap subjek masih belum bisa menerima atau menyetujui hasil akhir tersebut. Terkait dengan munculnya sistem yang direvisi, tidak menjadikan subjek bangga akan jerih payahnya selama melakukan resistensi, melainkan membuat subjek merasa kecewa. Hal ini dikarenakan hasil yang telah ditetapkan tidak sesuai dengan tuntutannya. Adanya perasaan kecewa yang dikeluarkan oleh subjek, terakumulasi dengan pemahaman bahwa sistem tersebut sangat merugikan buruh, sehingga muncul kekawatiran apabila terjadi pelanggaran lagi pada sistem outsourcing yang telah direvisi. Oleh karena itu pula, mereka merencanakan untuk melakukan aksi susulan agar sistem tersebut benar-benar dihapus. Pada umumnya resistensi buruh dengan tuntutan hapus outsourcing berupa aksi demonstrasi, namun secara khusus setiap subjek memiliki cara tersendiri untuk melengkapi resistensi tersebut. Resistensi tersebut berupa membuat kaos dengan tema HOSTUM (Hapus Outsourcing dan Tolak Upah Murah), menyebarkan isu akan ada aksi susulan, mengajak buruh-buruh yang lain untuk mengikuti aksi susulan, dan mengajak beberapa serikat untuk melakukan 
aksi susulan bersama.

\section{DAFTAR PUSTAKA}

Arifin, Syarif, dkk. (2012). Memetakan Gerakan Buruh (Antologi tulisan perburuhan mengenang Fauzi Abdullah). Depok : Kepik.

Chaplin, J. (2009). Kamus Lengkap Psikologi. Edisi Revisi cetakan ke-7. Jakarta: Rajawali Pers.

Damanik, S. (2006). Outsourcing dan Perjanjian Kerja: Menurut Undang-Undang No. 13 Tahun 2003 tentang Ketenagakerjaan, Jakarta: DSS Publishing.

Divisi Riset PPM Manajemen Tahun (2008) tentang Prosentase Keberadaan Outsourcing. Erman, E dan Saptari, R. (2013). Dekolonisasi Buruh Kota dan Pembentukan Bangsa, Jakarta: Yayasan Pustaka Obor Indonesia, KITLV-Jakarta.

Emzir. (2010). Metode Penelitian Kualitaitf. Jakarta: Erlangga.

Hasbi, S. (2012). Membincang Putusan Mahkamah Konstitusi: Outsourcing dan PKWT Langgar Konstitusi $11 \quad$ Oktober 2012. http:// komunitassekip.org/index.php/diskusimingguan/item/152-membincangputusan-mahkamah-konstitusi-outsourcing-dan-pkwt-langgar-konstitusi Diunduh pada 1 Desember 2012.

Iskandar. (2009). Metodologi Penelitian Kualitatif. Jakarta : Gaung Persada

Latupono, B. (2011). Perlindungan Hukum dan Hak "Perlindungan Hukum dan Hak Asasi Manusia Terhadap Pekerja Kontrak (Outsourcing) di Kota Ambon". Jurnal Sasi Vol. 17 No. 3 Bulan Juli-September X.

Muftakhir, A. (2012). Peneliti Lembaga Informasi Perburuhan Sedane (LIPS). Hukum yang Retak dan Grebek Pabrik (1). http://indo progress.com/hukum-yangretak-dan-grebek-pabrik-1/ Diunduh pada tanggal 2 Maret 2013.

Negara, S, E. (2010). Kedudukan Outsourcing di Indonesia. http: //the erlangga.wordpress.com/2010/09/03/kedudukan-outsourcing-diindonesia/ Diunduh pada 1 Desember 2012.

Piderit, K, S. (2000). Rethinking Resistance and Recognizing Ambivalence: A Multidimensional View of Attitudes Toward an Organizational Change. Academy of Management Review. Case Western Reserve University, No. 4, Vol. 25, 783-794.

Sihbudi, R dan Nurhasim, M. (2001). Kerusuhan Sosial di Indonesia, Studi Kasus Kupang, Mataram dan Sambas. Jakarta : Grasindo.

Sutedi, A. (2011). Hukum Perburuhan. Jakarta : Sinar Grafika.

Suriadi, A. (2008). Program Pascasarjana, Program Studi Sosiologi FISIP. "Resistensi Masyarakat Dalam Pembangunan Infrastruktur Perdesaan. Jurnal Komunitas Universitas Indonesia, No. 3, Vol. 4, hal. 52-69.

Undang-Undang Ketenagakerjaan (2003). Jakarta : Cemerlang.

Uti, I, R. (2009). "Pelindungan Hukum Terhadap Pekerja/ Buruh Outsourcing (Studi kasus di kabupaten ketapang)" Tesis Program Magister Ilmu Hukum, Program Pascasarjana, Universitas Dipoegoro Semarang.

Virianita, Markum, Ramdhan. M. (2003). "Pengaruh Identifikasi Kolektif dan Keyakinan Subyektif Mengenai Permeabilitas Kelompok Terhadap Partisipasi Buruh Dalam Aksi Unjuk Rasa. Jurnal Psikologi Fakultas Psikologi Universitas Indonesia Depok, Vol. 9. 